\title{
PENINGKATAN USAHA SUSU KEDELAI SKALA INDUSTRI RUMAH TANGGA DI TENGAH WABAH COVID'19
}

\author{
Yuli Ermawati 1 ; Nurleila Jumati 2 \\ Fakultas Ekonomi, Universitas Wijaya Putra Surabaya \\ yuliermawati@uwp.ac.id, nurleila@uwp.ac.id
}

\begin{abstract}
Abstrak
Banyak UMKM yang sempat terpuruk sejak wabah Covid'19 melanda dunia termasuk Indonesia. Salah satu UMKM tersebut adalah produsen susu kedelai atau sari dele. Mitra kami adalah produsen sekaligus pedagang susu kedelai di kecamatan Benowo Kelurahan Sememi Kota Surabaya. Keterbatasan IPTEK seperti pemasaran yang masih konvensional dan tidak adanya manajemen usaha serta keuangan menjadi faktor yang memperlambat perkembangan usahanya. Tujuan yang akan dicapai dalam program ini adalah perluasan pangsa pasar dengan menyentuh teknologi informasi, manajemen usaha dan tata keuangan yang lebih tertib, serta upaya pemanfaatan limbah hasil susu kedelai agar lebih produktif. Metode yang digunakan adalah pendampingan personal terhadap mitra. Langkah pendampingan dengan memberikan pelatihan dan pencerahan untuk manajemen usaha, pelabelan yang modern, pemasaran secara offline dan online agar jangkauan pasar mereka lebih luas. Selain itu juga memberikan inspirasi dan mendorong agar limbah yang dihasilkan susu kedelai bisa lebih bermanfaat. Hasil dari metode pendampingan yang diberikan adalah yang pertama kemasan produk untuk susu kedelai dirubah sedemikian rupa dan mulai dipasarkan secara online dan offline melalui sistem konsinyasi. Yang kedua adalah manajemen usaha menjadi lebih rapi dan didukung dengan pembukuan sederhana yang mulai rutin dilakukan. Yang ketiga adalah pemanfaatan hasil limbah pengolahan susu kedelai yaitu menjadi nugget,cookies, serundeng dan keripik dari ampas susu sari kedelai.
\end{abstract}

\section{Kata Kunci : Pemasaran, Susu Kedelai, UMKM}

\section{PENDAHULUAN}

Wabah yang secara global terjadi sejak akhir 2019 bernama COVID'19. Sebuah virus yang memiliki tingkat penyebaran sangat cepat dan membuat banyak negara terpuruk, termasuk Indonesia. Keadaan ini akan berdampak pada semua lapisan masyarakat baik dari tingkat atas sampai ke tingkat bawah. Dampak yang paling terasa adalah ekonomi. Banyak perusahaan yang tidak mampu membayar karyawannya sehingga harus merumahkan mereka. Dampak COVID-19 menjadi semakin terasa bagi
Indonesia karena sektor UMKM yang selama ini menjadi tulang punggung perekonomian menjadi sektor yang paling terdampak. Akibat penurunan ekonomi ini, sejumlah negara pun perlahan-lahan menerapkan new normal guna mendorong kembali roda perekonomian. Mereka secara perlahan-lahan mulai mencabut pembatasan sosial demi menyelamatkan pekerjaan masyarakat dan memulai kembali aktivitas perekonomian

Susu kedelai adalah produk minuman seperti susu sapi, tetapi dibuat dari kedelai. Susu

$$
\text { Ekonomi,Sosial,dan Budaya }
$$


kedelai merupakan minuman nabati bergizi tinggi. Salah satu pengusaha Susu Kedelai di Kecamatan Benowo Surabaya adalah mitra kami, Bapak Khamim Tohari yang lebih dikenal dengan panggilan Hari. Proses produksi Sari Kedelai Putune Eyang milik Bapak Hari masih tergolong konvensional. Usaha ini Beliau kelola sendiri dibantu sang istri tanpa adanya pembukuan. Sistem pemasaran yang dilakukan oleh Bapak Hari juga masih konvensional. Beliau menjajakan sari Kedelai dengan cara berkeliling. Beliau sering menerima pesanan sari Kedelai untuk acara olah raga di beberapa instansi pemerintah sekitar wilayah Kendung. Biasanya Bapak Hari mampu menghabiskan $5 \mathrm{~kg}$ kedelai dalam sehari.

Permasalahan yang dihadapi mitra PPM pedagang Sari Kedelai Putune Eyang berdasarkan obesrvasi dan wawancara terangkum dalam tabel 1 di bawah ini :

\section{Tabel 1. Permasalahan Mitra}

\begin{tabular}{|c|c|c|c|}
\hline No & $\begin{array}{l}\text { Aspek } \\
\text { Permasalahan }\end{array}$ & Permasalahan & Solusi \\
\hline 1. & $\begin{array}{l}\text { Packaging dan } \\
\text { Pemasaran }\end{array}$ & $\begin{array}{l}\text { Packaging/kemasan } \\
\text { masih konvensional } \\
\text { dengan plastik. } \\
\text { Belum ada } \\
\text { pengembangan } \\
\text { pemasaran secara } \\
\text { offline (dengan brosur } \\
\text { dan konsinyasi) } \\
\text { maupun online } \\
\text { (dengan } \\
\text { WA,FB,Market Place } \\
\text { lain) }\end{array}$ & $\begin{array}{l}\text { Pelatihan dan } \\
\text { pembuatan label merk, } \\
\text { packaging lebih menarik } \\
\text { dan modern, dan } \\
\text { pengembangan sistem } \\
\text { pemsaran online dan } \\
\text { offline (konsinyasi) }\end{array}$ \\
\hline 2 & $\begin{array}{l}\text { Pembukuan } \\
\text { Sederhana }\end{array}$ & $\begin{array}{l}\text { Belum ada pembukuan } \\
\text { sederhana untuk } \\
\text { melihat perkembangan } \\
\text { usaha }\end{array}$ & $\begin{array}{l}\text { Pelatihan dan } \\
\text { pendampingan } \\
\text { pembukuan sederhana }\end{array}$ \\
\hline 3 & $\begin{array}{l}\text { Pemanfaatan } \\
\text { Sisa Hasil } \\
\text { Produksi Sari } \\
\text { Kedelai }\end{array}$ & $\begin{array}{l}\text { Sisa hasil produksi } \\
\text { sari Kedelai (ampas) } \\
\text { dibuang begitu saja, } \\
\text { kadang ada UMKM } \\
\text { peternak yang minta } \\
\text { untuk dijadikan pakan } \\
\text { ternak }\end{array}$ & $\begin{array}{l}\text { Percobaan pengolahan } \\
\text { sisa / ampas sari kedelai } \\
\text { menjadi produk lain } \\
\text { bernilai tambah }\end{array}$ \\
\hline
\end{tabular}

\section{METODE PELAKSANAAN}

Metode yang digunakan adalah pendampingan personal terhadap mitra. Pelatihan dan pendampingan kami lakukan di rumah Mitra dan untuk konsinyasi kami lakukan kerjasama dengan beberapa toko,koperasi, dan kantin dekat area lokasi rumah mitra. Rencana yang akan dilakukan oleh tim adalah sebagai berikut :
(1)Untuk masalah di bidang pemasaran dan packaging, tim akan mengawal mereka membuat label dan kemasan yang modern dan praktis dengan merk yang mereka ciptakan (Putune Eyang). Lalu mendampingi mereka melalukan pemasaran secara offline dan online agar jangkauan pasar mereka lebih luas. Secara Offline produk tersebut akan dibuatkan brosur dan cooler box untuk dititipkan di warung dan kantin sekolah dan tempat lainnya dengan sistem konsinyasi, sedangkan secara online akan dilakukan dengan pembuatan kontak whatsapp dan pemasaran melalui market place. Untuk pemasaran online akan didahului dengan Pelatihan dan pendampingan IT yang melibatkan mitra dan istri mitra.(2) Untuk masalah keuangan, tim akan memberikan Pelatihan dan Pendampingan Pembuatan Pembukuan Sederhana untuk mengetahui perkembangan usaha mereka. Ini dilakukan oleh mitra dibantu istri.(3) Untuk masalah pengolahan hasil sisa/ampas sari kedelai, tim bersama mitra akan melakukan Percobaan Pemanfaatan sisa/ampas sari kedelai.

\section{HASIL DAN PEMBAHASAN}

Berdasarkan pada analisis situasi atas persoalan yang dihadapi oleh mitra serta solusi yang ditawarkan guna menyelesaikan persoalan prioritas tersebut, dalam hal ini dilakukan dalam dua tahapan kegiatan meliputi identifikasi dan implementasi IPTEK dan pendampingan penglolaan usaha

Kemasan dan Pemasaran. Kemasan sari kedelai dan sistem pemasaran sari kedelai mitra PPM Sari Kedelai pada awalnya masih tergolong konvensional karena hanya berkeliling antara 1 kampung ke kampung lainnya untuk menjual sari kedelainya yang dikemas dalam kemasan plastik. Tim kami memberikan beberapa pelatihan guna membantu sistem kemasan dan pemasarannya. Antara lain (1) Memberikan inspirasi dan pengetahuan tentang pentingnya kemasan dan label untuk meningkatkan nilai jual sari kedelai Bapak Hari, (2)Membantu pembuatan label dengan merk yang diinginkan mitra yaitu "Putune Eyang" dan alternatif kemasan botol plastik yang lebih higienis dan modern.(3)Pelatihan pemasaran offline sistem konsinyasi dibantu istri mitra dan mengawal usaha pelebaran pangsa pasar dengan sistem konsinyasi ke

$$
\text { Ekonomi,Sosial,dan Budaya }
$$


koperasi, kantin, maupun cafe yang bisa dijangkau.(4)Pelatihan pemasaran secara online dimulai dari pemasaran melalui Whatsapp, Facebook, dan Media Pemasaran lainnya.

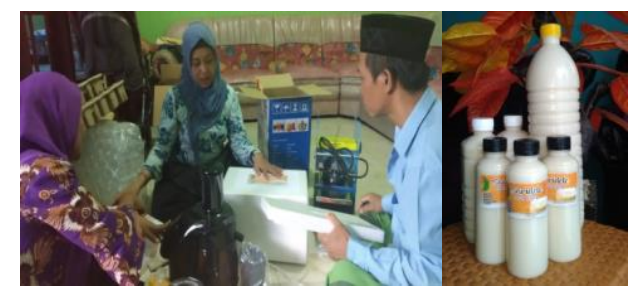

\section{Gambar 1. Pelatihan Kemasan}

Syarief dalam Yudha (2014) menerangkan bahwa terdapat hubungan antara kemasan dengan mutu produk yang dikemas. Pengemas akan menjaga produk dari perubahan aroma, warna, tekstur yang dipengaruhi oleh perpindahan uap air dan oksigen. Menurut Kotler dan Keller (2012), Kemasan yang baik dapat membangun ekuitas merek dan mendorong penjualan. Menurut Wirya, Iwan pada pada Susetyarsih (2012) daya tarik visual kemasan dapat digolongkan menjadi dua yaitu daya tarik visual dan daya tarik praktis

Pembukuan / Keuangan. Pada awalnya Mitra masih belum melakukan sistem pembukuan atau keuangan. Semua pemasukan dan pengeluaran hanya terlintas begitu saja sehingga terkadang uang untuk berjualan bercampur dengan uang belanja sehari-hari. Beliau juga tidak dapat memastikan berapa hasil penjualan tiap harinya dan berapa biaya produksi yang harus dikeluarkan. Ini semua karena keterbatasan pemahaman Beliau terhadap konsep keuangan. Menurut Ediraras (2010) Pengelolaan keuangan yang baik dan transparan memerlukan pengetahuan dan keterampilan akuntansi secara baik oleh pelaku UMKM.Setelah dilakukan pelatihan dan pendampingan pembukuan sederhana, kini Bapak Hari dibantu sang istri Ibu Nur memiliki pembukuan sederhana secara berkala. Dari hasil pembukuan sederhana ini, beliau akan dapat memantau perkembangan keuangan usaha Beliau

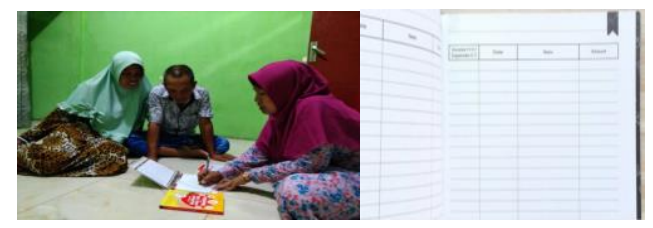

Gambar 2. Pelatihan Pembukuan Sederhana
Pemanfaatan Sisa Hasil Produksi Sari Kedelai. Sisa dari produksi sari kedelai adalah ampas sari kedelai yang disebut juga dengan okara. Okara ini pada awalnya dianggap barang yang sudah tidak bermanfaat, sehingga dibuang begitu saja. Terkadang juga ada peternak hewan setempat yang memanfaatkannya sebagai pakan ternak, namun ini hanya sebagai suplemen saja. Tim Pengabdian Masyarakat mencari refarensi dari hasil kajian ilmiah yang menyatakan bahwa ternyata Okara masih memiliki kandungan yang cukup bergizi dan bermanfaat bagi tubuh.

Okara memiliki kandungan serat makanan (dietary fiber) yang tinggi terutama kandungan protein kasar 28,36\%, lemak 5,52\%, serat kasar $7,6 \%$ dan juga mengandung asam amino lisin dan metionin serta vitamin B (Hulopi, 2014).

Ampas kedelai memiliki komposisi nutrisi yang tinggi yaitu 17, 4\% protein, 4,3\% mineral, $19 \%$ kalsium, $29 \%$ fosfor, $398 \%$ energy, 67, 5\% kharbohidrat $4 \%$ zat besi sehingga ampas tahu bermanfaat untuk pertumbuhan dan kesehatan tubuh (Surparti dalam Sartika, 2017)

Berdasarkan hasil kajian tersebut maka Tim Pengabdian Masyarakat memberikan pemahaman dan sugesti kepada Bapak Tohari untuk memanfaatkannya sebagai olahan makanan lainnya. Dengan beberapa kali percobaan maka hasil yang terpilih adalah pembuatan nugget okara, kukis okara, serundeng okara, dan keripik okara.

Cara pembuatan Nugget okara yaitu mencampurkan 300gr okara yang sudah disortir dengan 100gr tepung tapioka dan 100gr tepung maizena, 2 butir telur, bumbu,dan campuran secukupnya (sayur untuk nugget sayur dan isian coklat untuk nugget bola coklat). Setelah itu dicetak diatas loyang atau wadah tahan panas. Setelah itu dikukus kurang lebih 30 menit. Setelah matang, dibasahi dengan cairan tepung terigu encer dan diberi taburan tepung roti atau tepung panir. Setelah itu nugget siap digoreng dan disajikan hangat. Namun jika tidak langsung digoreng, nugget bisa disimpan didalam freezer (frozen) 

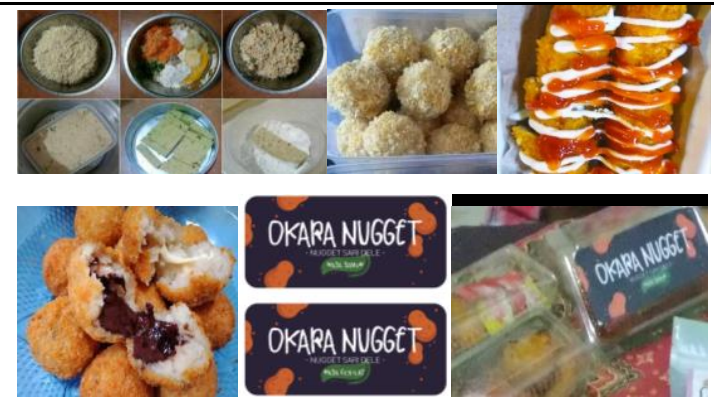

Gambar 3. Proses Pembuatan Nugget Okara beserta label dan kemasan

Cara pembuatan kukis okara yaitu dengan mengocok 60gr mentega atau roombutter, 1 butir kuning telur, 50gr gula halus, dan vanila dengan mixer hingga merata. Kemudian ditambahkan dengan $150 \mathrm{gr}$ terigu dan $50 \mathrm{gr}$ okara yang sudah disangrai. Uleni sampai kalis dan tambahkan topping chocochips atau almond. Ambil sebagian dan cetak diatas loyang, olesi dengan kuning telur. Panggang kue dalam oven dengan suhu 140 'C selama \pm 20 menit hingga matang. Angkat dan diamkan hingga dingin, kemudian masukkan dalam wadah kedap udara

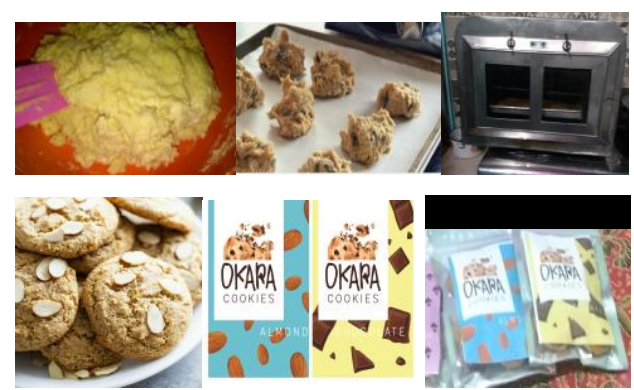

Gambar 4. Proses Pembuatan Kukis Okara beserta label dan kemasan

Cara pembuatan serundeng okara yaitu sangrai 400gr okara dengan daun salam, daun jeruk, asam jawa dan $2 \mathrm{~cm}$ lengkuas hingga setengah kering. Masukkan bumbu halus 1 (10 buah bawang putih, 5 buah bawang merah, 4 buah cabai merah besar, cabai rawit, $3 \mathrm{~cm}$ kunyit) sampai tercampur rata. Masukkan bumbu halus 2 ( 1 sdt ketumbar bubuk, $1 / 2$ sdt merica bubuk, 3 butir kemiri, 2 sdt gula merah sisir). Tambahkan campuran tempe goreng kering, kacang goreng, daging goreng atau teri goreng secukupnya. Sangrai hingga kering \pm 1 jam. Angkat dan diamkan hingga dingin. Simpan dalam wadah tertutup

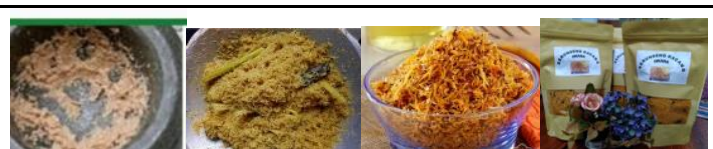

Gambar 5. Proses Pembuatan Serundeng Okara

Cara pembuatan keripik okara yaitu Campurkan rata 500gr okara, 500gr tepung tapioka dan bumbu yang telah dihaluskan (60gr bawang putih, 15gr garam, 5gr gula, penyedap rasa secukupnya). Masukan adonan ke dalam plastik dan bentuk persegi memanjang. Kukus adonan sampai matang $( \pm 2$ jam). Dinginkan adonan dan disimpan sampai mengeras. Iris adonan tipis-tipis dan jamur sampai kering sehingga menjadi krecekan. Goreng krecekan keripik okara. Biarkan dingin (bisa ditambah dengan perasa pedas atau manis) dan simpan dalam wadah kedap udara

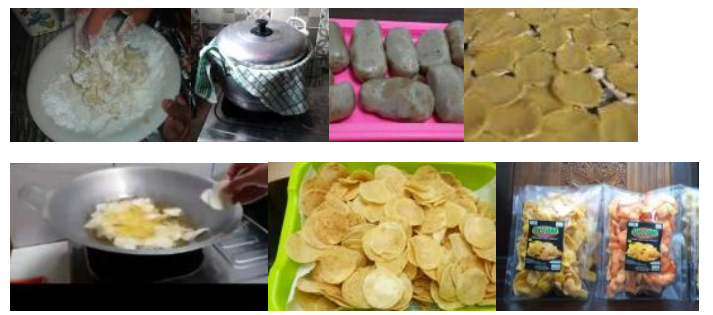

Gambar 6. Proses Pembuatan Keripik Okara
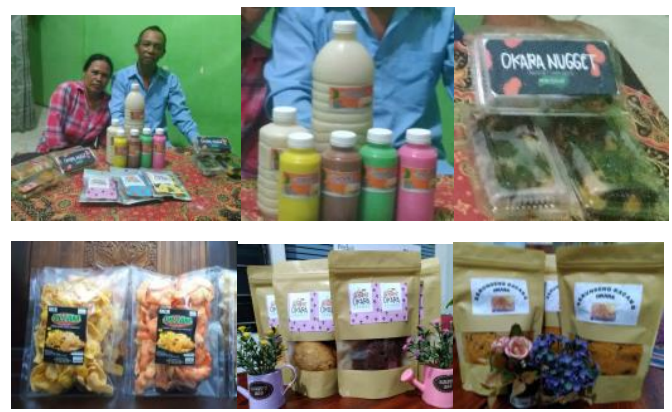

Gambar 7. Mitra "Putune Eyang" dan Produk

\section{SIMPULAN DAN SARAN}

(1)Setelah dilakukan pelatihan dan pendampingan, kini packaging/kemasan sari kedelai Putune Eyang menjadi lebih menarik, modern, praktis, dan lebih bertahan lama. Selain itu juga terdapat penamaan/merk untuk hasil produksi mitra. (2)Setelah dilakukan pelatihan dan pendampingan pemasaran secara offline dan online, kini pemasaran produk mitra dilakukan melalui offline dengan

$$
\text { Ekonomi,Sosial,dan Budaya }
$$

1187 
sistem konsinyasi (menitipkan produk ke toko, kantin, koperasi dan supermarket terdekat) melalui online dengan whatsapp, facebook, dan media pemasaran online lainnya (Marketplace) dan memiliki persiapan untuk menuju aplikasi makanan online (Go Food, Grab Food). (3)Terdapat pembukuan sederhana secara berkala setelah dilakukan pelatihan dan pendampingan pembukuan. Untuk pembukuan mitra dibantu oleh sang istri. (4)Setelah diberikan pemahaman, inspirasi, dan pendampingan, muncul inovasi baru pengolahan sisa hasil produksi sari kedelai yaitu dalam bentuk nugget okara (sayur dan coklat), okara cookies (almond dan chips), serundeng okara, dan keripik okara (balado,keju,original)

Saran (1)Perlu terus menemukan inovasi dalam proses produksi dan pengemasan untuk lebih meningkatkan keawetan hasil produksi terutama sari kedelai.(2)Tetap konsisten melanjutkan pembukuan secara berkala dan tertib.(3)Lebih gencar dalam memasarkan produk dan menggunakan sarana media baik cetak maupun elektronik.

\section{UCAPAN TERIMAKASIH}

Ucapan terimakasih disampaikan kepada 1) Bapak Khamim Tohari selaku mitra pengabdian masyarakat susu kedelai, 2) LPPM Universitas Wijaya Putra yang memberikan kesempatan kepada tim untuk melaksanakan program pengabdian masyarakat kepada UMKM Susu Kedelai di Kecamatan Benowo Surabaya., 3) Universitas Wijaya Putra yang memberikan dana dan dukungan untuk pelaksanaan program pengabdian masyarakat

\section{DAFTAR PUSTAKA}

Bigliardi, B., Pierluigi, \& Dormio, A. I. (2011). Innovative Caharcteristics of Small and Medium Enterprises. Journal of Technology Management \& Innovation, 6(22), 83-93

Ediraras, Dharma. Akuntansi dan kinerja UMKM. (2010). Jurnal Ekonomi Bisnis. 2 (15), 152-158
Hulopi, F. (2014). Pemanfaatan Ampas Susu Kedelai sebagai Tepung Subtitusi dalam Pengolahan Kerupuk. Tugas Akhir. Universitas Negeri Gorontalo

Putri, Anggi Dwi et all.(2018). Analisis Gizi Limbah Ampas Kedelai Sebagai Tepung Substitusi Mie untuk Menunjang Sumber Belajar Mata Kuliah Biokimia. Jurnal Pendidikan Biologi dan Sains. Volume 1, No 1, Juni 2018 e-ISSN : 2598-7453

Prasetyawan,Yudha,et all (2014). Peningkatan Produktivitas Usaha Kecil Menengah Kerupuk Udang Melalui Perancangan Pengeringandan Pengemasan. Jurnal metris, 15 (2014), 7-14

Sartika, Hermiza. (2017). Pengaruh Penambahan Tepung Ampas Tahu Terhadap Karakteristik Biskuit yang Dihasilkan. Jurnal Teknologi Pertanian. Vol. 6, No. 1, Tahun 2017

Suryana, 2003. Kewirausahaan. Pedoman Praktis. Kiat dan Proses Menuju Sukses. Jakarta: Salemba Empat

Susetyarsih (2012). Kemasan Produk Ditinjau dari Bahan Kemasan, Bentuk Kemasan, dan Pelabelan pada Kemasan. Jurnal STIE Semarang. 4(3), 19-28 